\title{
Geology, petrology and geochemistry of the dome complex of Huequi volcano, southern Chile
}

\author{
Sebastian F.L. Watt ${ }^{1,2}$, David M. Pyle ${ }^{1}$, Tamsin A. Mather ${ }^{1}$ \\ ${ }^{I}$ Department of Earth Sciences, University of Oxford, Parks Road, Oxford OX1 3PR, U.K. \\ Sebastian.Watt@noc.soton.ac.uk; David.Pyle@earth.ox.ac.uk; Tamsin.Mather@earth.ox.ac.uk \\ ${ }^{2}$ School of Ocean and Earth Science, National Oceanography Centre, Southampton, University of Southampton, European Way, \\ Southampton SO14 3ZH, U.K.
}

\begin{abstract}
Huequi, a little-known volcano in the southern part of the Andean southern volcanic zone (SSVZ), shows a regionally unusual eruption style, mineralogy and geochemistry. The volcano comprises multiple highly-eroded lava domes. Past eruptions were accompanied by relatively minor explosive activity, most recently from 1890-1920. The rocks erupted by Huequi range from basaltic andesite to dacite, and are highly distinctive when compared to other volcanoes of the SSVZ, being K-poor and Al-rich, and containing euhedral hornblende phenocrysts. Overall compositions suggest a notably water-rich magma source, evolving through high levels of fractionation and subsequent degassing to produce highly porphyritic dome-forming andesites. The ultimate causes of water-rich magmas at this point in the arc remain unclear.
\end{abstract}

Keywords: Huequi volcano, Andean southern volcanic zone, Andesite, Amphibole, Lava dome.

RESUMEN. Geología, petrología y geoquímica de los domos volcánicos del volcán Huequi, Chile meridional. El volcán Huequi es poco conocido, que se ubica en la provincia sur de la zona Volcánica Sur de los Andes (ZVSS). Sus tipos de erupción y características mineralógicas y geoquímicas son poco comunes a nivel regional. El volcán presenta múltiples domos poco erosionados. Las erupciones estuvieron acompañadas por una actividad explosiva secundaria, siendo las más recientes las ocurridas entre los años 1890 y 1920. Los magmas del Huequi son de composición andesítico-basáltica a dacítica. Si se las compara con rocas eruptadas por otros centros volcánicos de la ZVSS de los Andes, las del Huequi se caracterizan por ser pobres en $\mathrm{K}$, ricas en $\mathrm{Al}$ y por presentar fenocristales euhedrales de anfíbola. Las composiciones totales sugieren una fuente magmática rica en $\mathrm{H}_{2} \mathrm{O}$, que se desarrolla a través de niveles de cristalización fraccionada y desgasificación subsecuente, que producen domos volcánicos andesíticos altamente porfíricos. Sin embargo, la causa última que genera magmas ricos en $\mathrm{H}_{2} \mathrm{O}$, en esta parte de los Andes, sigue aún sin explicación. 


\section{Introduction}

Huequi volcano $\left(42.4^{\circ} \mathrm{S}, 72.6^{\circ} \mathrm{W}\right)$ lies in the centre of the isolated Ayacara peninsula, in southern Chile (Fig. 1). It is situated on the arc front of the southern part of the Andean southern volcanic zone (SSVZ; López-Escobar et al., 1995a; Stern, 2004), 50 km south of Hornopirén volcano, and a similar distance north of Chaitén and Minchinmávida (Siebert and Simkin, 2002). Historical explosive eruptions are documented from the volcano between 1890 and 1920 (González-Ferrán, 1995) although little is known about the nature or magnitude of this activity. Due to its remote location, in a densely forested and sparsely populated region, the volcano has not been previously studied in any detail. The purpose of this paper is to provide an overview of the volcanic geology of Huequi, based on field observations and sampling, and to place this within a regional context.
The Ayacara peninsula, bounded by a fjord to the east, which forms part of the regional scale Liquiñe-Ofqui fault zone (Cembrano et al., 1996; Fig. 1), and by the Gulf of Ancud to the west, is inaccessible by road. The only settlements in the area are small coastal villages, and access to Huequi volcano is most easily made by following the Huequi river SSE from the coast to the volcano, $20 \mathrm{~km}$ away.

Fuenzalida Izquierdo (1979) described the geology of the Ayacara peninsula, mapping the area as a series of fault-bounded metamorphic and granitoid basement blocks, and also identifying three small volcanic centres SE of Huequi, likely to be of late Pleistocene age, but otherwise unknown. The geology of Huequi volcano itself has not been mapped previously, and its products have not been widely sampled. Published analyses of volcanic rocks from the area are limited to two andesitic lavas from Huequi, described in the regional-scale study of López-Escobar et al. (1993).
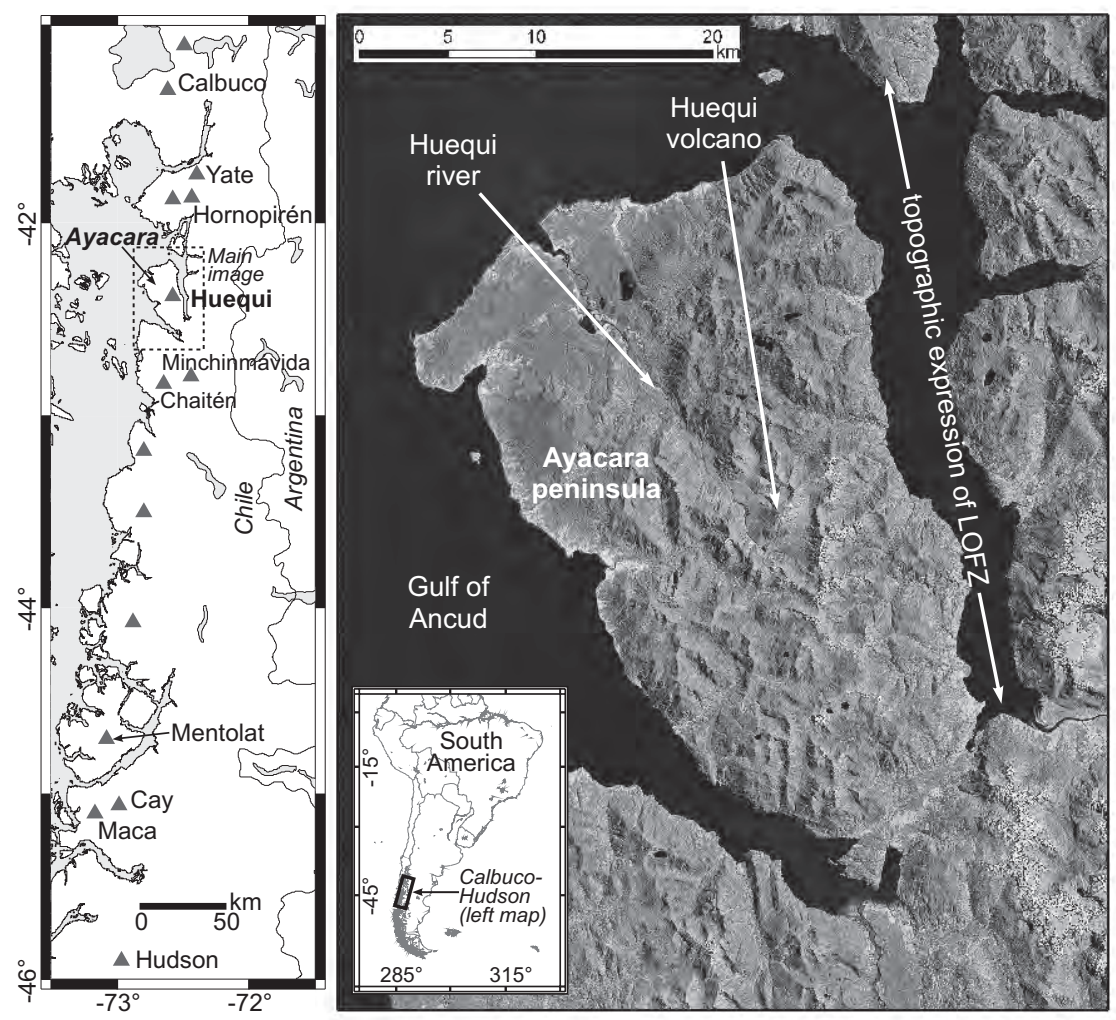

FIG. 1. The left map shows Huequi and other volcanoes of the SSVZ. The main Landsat image (NASA Landsat Program, USGS) shows the isolated location of Huequi on the Ayacara peninsula, and the inset map of South America indicates the position of the SSVZ. 


\section{Morphology and geology}

\subsection{Setting}

Huequi is situated towards the northern end of the SSVZ, which stretches from Yate to Hudson (Fig. 1; López-Escobar et al., 1995a; Stern, 2004). Calbuco, immediately north of Yate, is also included here within the studied arc segment. The SSVZ is characterised by subduction of the Nazca plate beneath relatively thin $(\sim 30 \mathrm{~km})$ South American continental crust, and the volcanic rocks of the region are, in general, subject to relatively small amounts of magmatic evolution, widely erupting basalts and basaltic andesites (López-Escobar et al., 1993).

The results presented here are based upon field sampling around Huequi volcano from $20^{\text {th }}-23^{\text {rd }} \mathrm{Fe}-$ bruary 2008. Samples were collected and observations made along the Huequi river and around the north flank of the volcano (Fig. 2). The south side of the volcano was inaccessible and could not be mapped. From these observations, the geological map in figure 2 has been constructed. Petrological and geochemical results will be summarised in subsequent sections.
Huequi is topographically subdued in comparison with other SSVZ arc frontal volcanoes, with an unglaciated summit of just over $1,300 \mathrm{~m}$, from a base at $\sim 400 \mathrm{~m}$. The edifice is deeply eroded, and the NW approach to the volcano is dominated by a thick sequence of collapse deposits. Rocks exposed in the upper portion of the edifice show that the volcano consists of multiple lava domes, eroded and concealed by collapse deposits, obscuring chronological relationships. The volcano lies within a depression defined by a curved structure around its eastern and southern margins. To the east, this structure appears to relate to faulting in basement rocks, but its morphology may also in part reflect an early, large collapse of the volcano, potentially generating much of the debris accumulated to the north-west, and forming a depression in which younger domes are now nested. The summit is presumed to date from the most recent activity in the early $20^{\text {th }}$ century, forming a steep sided dome, partially collapsed on the NW side, where a deep valley incises the edifice and has provided a route for multiple debris avalanches, accumulating on the fan to the west (Fig. 3).

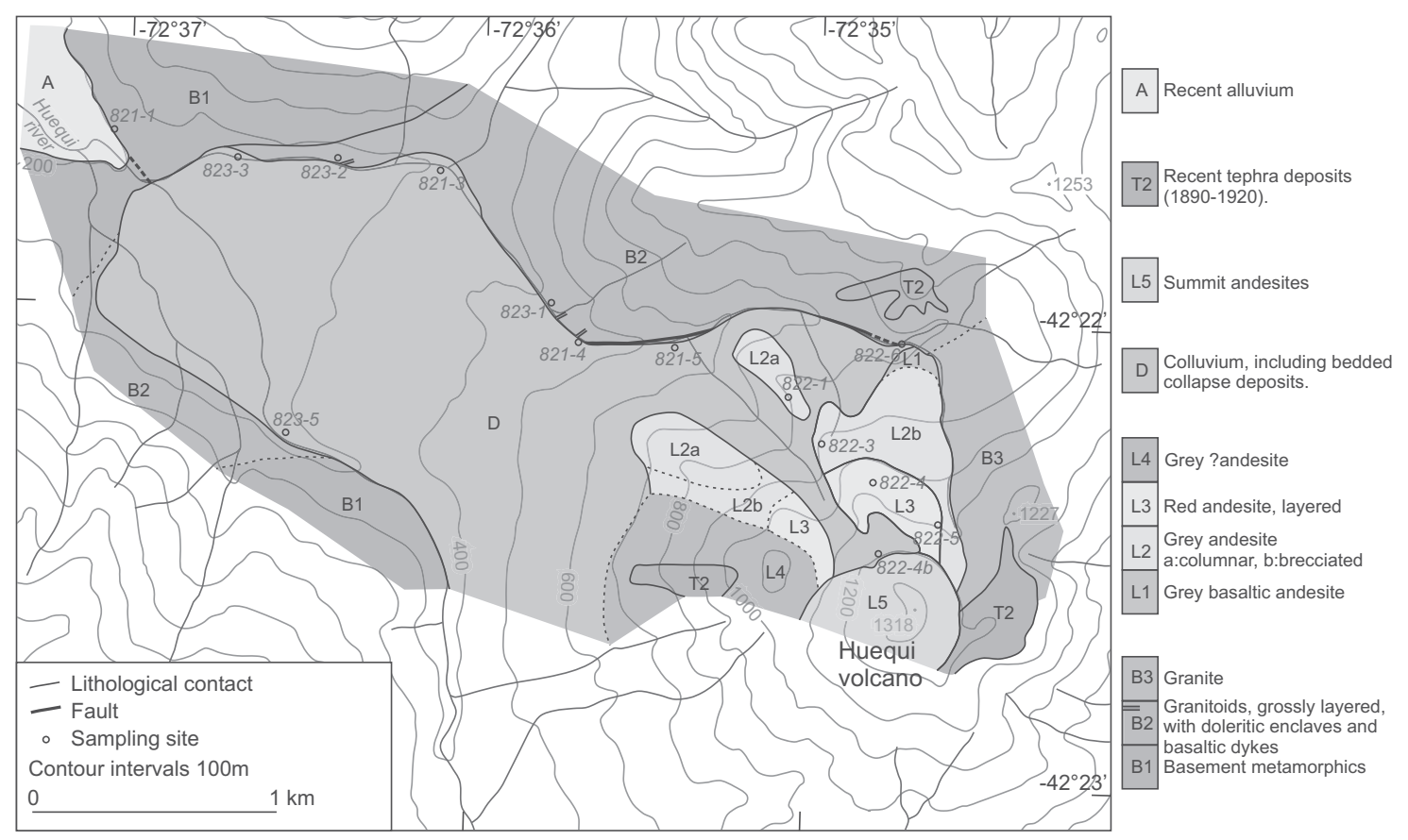

FIG. 2. Main panel: geological sketch map based on the fieldwork and results described in this paper. The edifice is surrounded by extensive debris deposits. The exposed summit comprises a series of lava domes. Dashed lines indicate geological contacts of uncertain position. Red circles with numbers indicate sampling locations. 


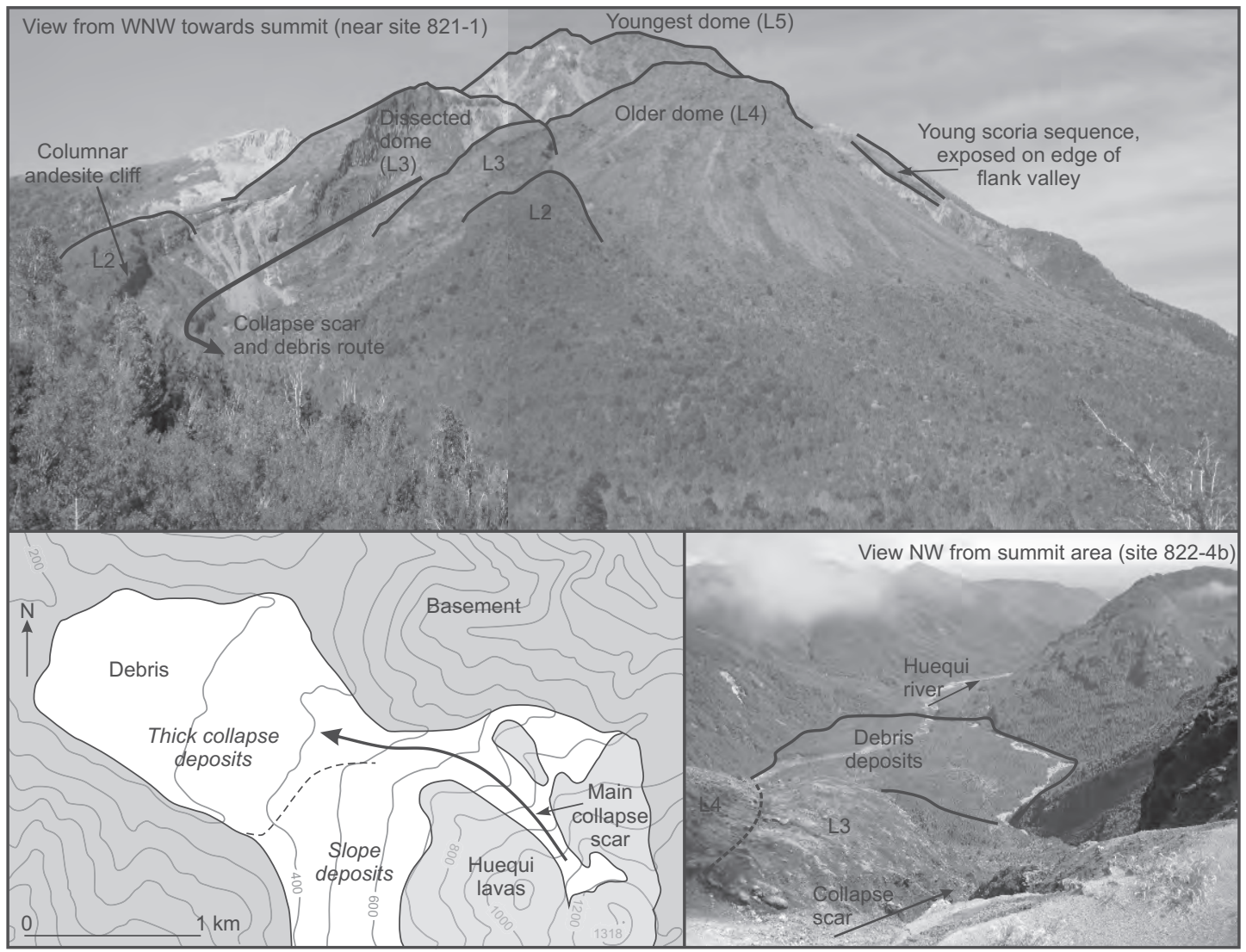

FIG. 3. Top: view from near site 821-1 (Fig. 2) towards the volcano summit, differentiating the units defined in figure 2; Lower left: extent of debris deposits NW of Huequi, showing the route of debris generated by dome collapse; Lower right: view from above the main collapse scar (site 822-4b; Fig. 2) towards the NW.

\subsection{Collapse units}

The extensive collapse units NW of the main edifice are formed of poorly sorted, coarse-grained chaotic deposits, dominated by porphyritic lava blocks, and also containing entrained lithics from the surrounding basement and occasional rounded pumices. These gravity driven collapse deposits were not highly mobile, potentially losing energy against the steep topography to the north, and restricted by this surrounding topography to build thick deposits at the base of the volcano. There is no clear evidence of syn-eruptive collapse. Although highly fragmented, most of the lava blocks within the collapse deposits show little weathering or alteration. River-incised exposures along the north and west side of the debris deposits indicate at least three main collapses, with each unit forming a bed on a 2-5 $\mathrm{m}$ scale, cut as individual terraces along the river west of the volcano. Debris cover higher on the west flank is likely to be formed of thinner slope talus (Fig. 3). Lava blocks within the debris deposits are dark grey porphyries, of the type characterising the older eroded dome units around the summit. The paler grey and pink porphyries of the youngest dome are absent, indicating that the debris units represent large scale dome collapses in the past, rather than events during the most recent (1890-1920) phase of activity. Vegetation on the debris deposits forms a dense cover, with mature trees that are not noticeably younger than those on slopes away from the volcano.

\subsection{Lava domes}

The youngest dome sits at the head of the NW collapse scar. This scar exposes older dome rocks, which can be traced across the valley. All these rocks are dense porphyries, but massive columnar jointed 
sequences, forming prominent, isolated cliffs, are distinct from more eroded dome breccias, which are well exposed on the upper slopes and at the headwall of the collapse scar (Figs. 2 and 3). Here also, a range of colouration and fracturing within the young dome suggests hydrothermal alteration.

The occurrence of repeated dome-forming eruptions at Huequi, predominantly of andesitic composition, is regionally unusual. With the exception of the rhyolitic centre of Chaitén (which is also compositionally highly anomalous in a regional context; cf. López-Escobar et al., 1993; Watt et al., 2009), the arc frontal volcanoes of the SSVZ are generally much larger edifices, characterised by significant volumes of lava flows, with minor cinder cones and occasional large explosive eruptions (e.g., Naranjo and Stern, 2004). The eruptive style at Huequi may ultimately result from its magmatic composition (see Section 4 below), which is unique within the SSVZ, with initial water-rich compositions subject to gas exsolution upon ascent producing a highly viscous, crystal-rich andesite (cf. Sparks et al., 2000).

\subsection{Tephra deposits}

Although the activity of Huequi is dominated by repeated lava dome formation, interspersed with large collapses, tephra deposits around the volcano indicate periods of moderate explosive activity, as commonly accompanies dome-forming eruptions. A bed of white pumice (here named T1) is exposed in the uppermost part of the collapse scar walls. This unit, $\sim 600 \mathrm{~m} \mathrm{NW}$ of the present summit and $1 \mathrm{~m}$ thick, contains clasts of up to $10 \mathrm{~cm}$ diameter, suggesting a moderately large explosive eruption. Chemically (see Section 4), the pumice is consistent with other Huequi products, but is more silicic than any other samples found here. The unit is likely to be the source of pumice grains that can be found washed along the Huequi river as far as the coast. The unit is overlain by $2 \mathrm{~m}$ of sand-sized pyroclastic windblown debris, stabilised by limited plant growth on the upper slopes. The position of the unit near the surface suggests its eruption may have followed the last large dome collapse, but was prior to the most recent activity.

Much thicker tephra deposits (here named T2) are sparsely preserved around the volcano as patches on the ground surface, without significant cover. They are therefore presumed to date from the 1890-1920 eruptive period. There are few locations suitable for fall deposit preservation, due to the surrounding steep topography. This is also likely also to account for the very limited exposure of the white pumice deposit. The 1890-1920 tephra sequence is most thickly developed immediately east of the summit (Fig. 4), where it is preserved on a small plateau. Elsewhere, patches occur on nearby slopes. The grains of this unit are dense and rounded; a crystal-rich dense grey pumice (T2(P)) forms the base, beneath a thick, stratified black scoria sequence (T2(S)), with a red scoria bed in its lower part. Compositionally,

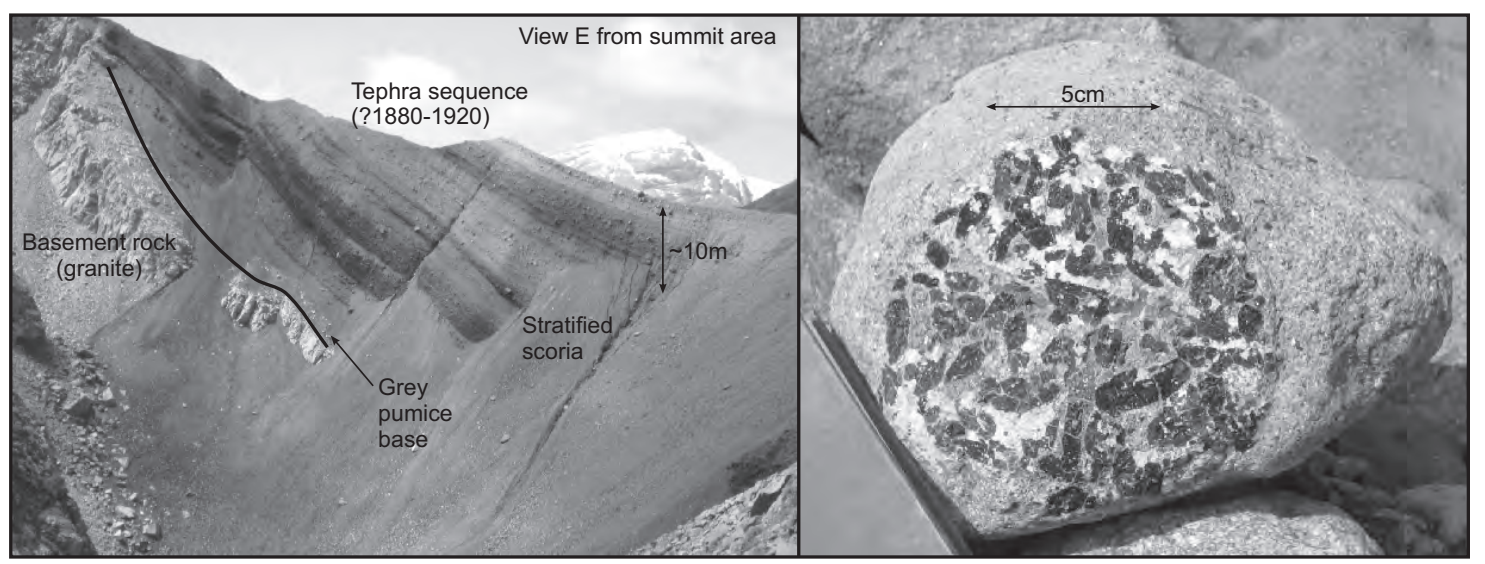

FIG. 4. Left: the structure of the T2 fall deposit, immediately east of the summit (taken from site 822-4b; Fig. 2). Right: a loose lava block, probably from L5, exposing a rounded clot of plagioclase and hornblende, in equilibrium with the host lava. Hornblendes of similar size are also found as single crystals within these rocks, particularly in L1 and L5. 
the dense grey pumice and black scoria are indistinguishable, suggesting the colour reflects a slightly lower density to the pumice, although all of the tephra are relatively poorly vesicular. The unit points to a series of cyclic, possibly Vulcanian, explosions during the latter part of the youngest eruptive period, with an early, more gas-rich phase producing the grey pumice. Although no distal tephra units from Huequi have been previously identified, the tephra deposits found here indicate the potential existence of deposits originating from Huequi, preserved at suitable sites east of the Andes, which may be used to constrain the magnitude and age of these eruptions.

\section{Petrography}

The mineralogy of sampled lavas, examined in thin section, is summarised in Table 1. Mineral compositions were measured using a scanning electron microscope (JEOL JSM-840A) with an energy dispersive system (Oxford Instruments Isis-300).

All the sampled Huequi lavas are petrologically highly similar. A basaltic andesite $\left(55 \mathrm{wt} \% \mathrm{SiO}_{2}\right)$ outcrops near the base of the edifice on the northern flank (L1; Fig. 2), and is considered to be the oldest sampled lava, while all remaining samples (L2-5) are andesites $\left(\sim 59 \mathrm{wt} \% \mathrm{SiO}_{2}\right)$. Explosive eruption products show more variation: the $\mathrm{T} 2$ fall deposit is basaltic andesite (53-54 wt $\% \mathrm{SiO}_{2}$ ), and the older white pumice (T1) a dacite $\left(62 \mathrm{wt} \% \mathrm{SiO}_{2}\right)$. Mineralogically, all these samples form a consistent suite. The phenocryst phase is dominated by euhedral plagioclase, commonly with strong normal zoning. Some blocky grains display sieve-textured cores, in contrast to abundant clean tabular grains. Orthopyroxene, com- monly associated with plagioclase in glomerocrysts, forms a secondary phenocryst phase, comprising tabular grains down to a microphenocrystal scale, pale yellow in thin section, often with thin alteration rims. Hornblende is a third phenocryst phase, less frequent than orthopyroxene, and very uncommon in some samples. The same phenocryst phases are identifiable in the T2 deposit. Example phenocryst core compositions of hornblende, plagioclase and orthopyroxene are given in Table 2 .

The rocks of the summit dome (L5; Fig. 2) range from pale grey to pink in colour, and are dense porphyries. The colour difference relates to late-stage oxidation, with orthopyroxenes in the pink samples displaying thin alteration rims. These are the only Huequi rocks in which olivine is present, as small rounded grains $\left(\mathrm{Fo}_{69-75}\right)$, rimmed by orthopyroxene. Quartz also occurs as very occasional, possibly xenocrystal grains. The dome immediately west of the summit, representing the preceding phase of activity, was inaccessible for sampling. Given the relatively homogeneous composition of the other young dome rocks and of the debris on north-west slopes of Huequi, it is likely that this dome is also andesitic. The red-brown breccia of L3 contains little amphibole, in common with the older L2 lavas. The dense grey lavas of L2, present as both columnar and brecciated units, are the only sampled rocks to contain augite as a phenocryst phase, although always with an orthopyroxene rim. These rocks are more porphyritic than the other andesites. The basal basaltic andesite (L1) also contains augite, but as a stable groundmass phase. This rock has less frequent oxides, the majority being the result of late stage hornblende alteration.

TABLE 1. SUMMARY MINERALOGY OF THE HUEQUI DOME LAVAS.

\begin{tabular}{|c|c|c|c|c|c|c|c|c|c|c|c|c|c|}
\hline \multirow{2}{*}{ Unit } & \multirow{2}{*}{ Samples } & \multicolumn{6}{|c|}{ Phenocrysts } & \multicolumn{6}{|c|}{ Groundmass } \\
\hline & & Plag & Opx & Hbl & Aug & OI & Qtz & Plag & Opx & Aug & Qtz & Ox & Ap \\
\hline L1 & $822-6 B$ & $\mathrm{xxx}$ & $\mathrm{xxx}$ & $\mathrm{xxx}$ & - & - & - & $\mathrm{xxx}$ & $\mathrm{xxx}$ & $\mathrm{x}$ & - & $\mathrm{xx}$ & $\mathrm{xx}$ \\
\hline $\mathrm{L} 2$ & $822-3 \mathrm{~A}, 6 \mathrm{E}$ & $\mathrm{xxx}$ & $\mathrm{xxx}$ & $\mathrm{x}$ & $\mathrm{xx}$ & - & - & $\mathrm{xxx}$ & $\mathrm{xxx}$ & - & $\mathrm{xx}$ & $\mathrm{xxx}$ & $\mathrm{xx}$ \\
\hline L3 & $822-4 \mathrm{E}$ & $\mathrm{xxx}$ & $\mathrm{xxx}$ & $\mathrm{x}$ & - & - & - & $\mathrm{xxx}$ & $\mathrm{xxx}$ & - & $\mathrm{xx}$ & $\mathrm{xxx}$ & $\mathrm{xx}$ \\
\hline L5 & $822-4 \mathrm{~A}, 4 \mathrm{~B}, 4 \mathrm{C}, 4 \mathrm{D}, 4 \mathrm{~F}$ & $\mathrm{xxx}$ & $\mathrm{xxx}$ & $\mathrm{xx}$ & - & $\mathrm{x}$ & $\mathrm{x}$ & $\mathrm{xxx}$ & $\mathrm{xxx}$ & - & $\mathrm{xx}$ & $\mathrm{xxx}$ & $\mathrm{xx}$ \\
\hline
\end{tabular}

xxx: abundant; xx: frequent; x: rare; Plag: plagioclase; Opx: orthopyroxene; Hbl: hornblende; Aug: augite; Ol: olivine; Qtz: quartz; Ox: oxides (see text); Ap: apatite. 
TABLE 2. EXAMPLE MINERAL ANALYSES FOR PHENOCRYST CORE COMPOSITIONS (OXIDE wt\%).

\begin{tabular}{lrrrrrrrr}
\hline & \multicolumn{4}{c}{ Hornblende } & \multicolumn{2}{c}{ Plagioclase } & \multicolumn{2}{c}{ Orthopyroxene } \\
\cline { 2 - 9 } Unit & $\mathbf{L 5}$ & $\mathbf{L 5}$ & $\mathbf{L 2}$ & $\mathbf{L 1}$ & $\mathbf{L 5}$ & $\mathbf{L 1}$ & $\mathbf{L 5}$ & $\mathbf{L 2}$ \\
\cline { 2 - 9 } Sample & $\mathbf{2 2 - 4 A}$ & $\mathbf{2 2 - 4 D}$ & $\mathbf{2 2 - 3 A}$ & $\mathbf{2 2 - 6 B}$ & $\mathbf{2 2 - 4 F}$ & $\mathbf{2 2 - 6 B}$ & $\mathbf{2 2 - 4 A}$ & $\mathbf{2 2 - 3 A}$ \\
\hline $\mathrm{SiO}_{2}$ & 42.62 & 41.63 & 44.01 & 42.60 & 44.55 & 44.66 & 52.51 & 51.86 \\
$\mathrm{TiO}_{2}$ & 1.98 & 2.57 & 2.74 & 2.30 & 0.08 & - & 0.26 & 0.26 \\
$\mathrm{Al}_{2} \mathrm{O}$ & 13.33 & 14.18 & 11.63 & 13.57 & 36.21 & 35.53 & 1.48 & 0.77 \\
$\mathrm{FeO}$ & 13.82 & 11.21 & 14.09 & 13.06 & 0.46 & 0.47 & 24.75 & 20.62 \\
$\mathrm{MnO}$ & 0.27 & 0.12 & 0.30 & 0.12 & 0.05 & - & 0.94 & 0.85 \\
$\mathrm{MgO}$ & 13.69 & 14.99 & 13.94 & 14.33 & 0.41 & 0.53 & 20.53 & 22.51 \\
$\mathrm{CaO}$ & 11.16 & 11.30 & 11.51 & 11.35 & 19.05 & 18.58 & 0.89 & 1.60 \\
$\mathrm{Na}$ & 2.45 & 2.53 & 2.62 & 2.25 & 0.77 & 1.10 & 0.31 & 0.30 \\
$\mathrm{~K}_{2} \mathrm{O}$ & 0.19 & 0.28 & 0.22 & 0.21 & 0.04 & - & - & - \\
\hline
\end{tabular}

Analyses by scanning electron microscope (JEOL JSM-840A) with an energy dispersive system (Oxford Instruments Isis-300), at Oxford University, U.K.

The groundmass of the andesites is dominated by plagioclase and orthopyroxene, as well as extremely fine grained quartz, absent from the basaltic andesite, and an interstitial high-silica glass. Oxide grains are generally Ti-magnetite; associated ilmenite is present only in the L5 lavas. Apatite is widespread, associated with orthopyroxene.

Plagioclase phenocrysts, particularly the larger, blocky grains, are commonly of a high-Al high-Ca type (up to $\mathrm{An}_{93}$; Fig. 5). Groundmass grains, as well as some clean tabular phenocrysts, are less anorthitic $\left(\mathrm{An}_{50-60}\right)$. Those in the basaltic andesite are all $>\mathrm{An}_{60} . \mathrm{L} 5$ rocks are distinctive in containing, albeit infrequently, groundmass grains of the highly anorthitic type. The bimodal distribution of compositions across the whole suite (Fig. 5) suggests two separate populations rather than a continuum, the less anorthitic type being in equilibrium with the erupted lava. The anorthitic phenocrysts suggest derivation from a less-evolved, hotter magma; magmatic mixing is also suggested by out-ofequilibrium olivines and augites in L5 and L2 respectively. Orthopyroxene phenocryst core compositions classify as hypersthenes (Fig. 5): those for units L1-L3 overlap, while compositions in
L5 are subtly different, containing marginally less $\mathrm{Ca}$ and extending to slightly more ferrous compositions. Groundmass and phenocryst rim compositions (not shown in figure 5) are similar, but are in some cases slightly more magnesian, while grains
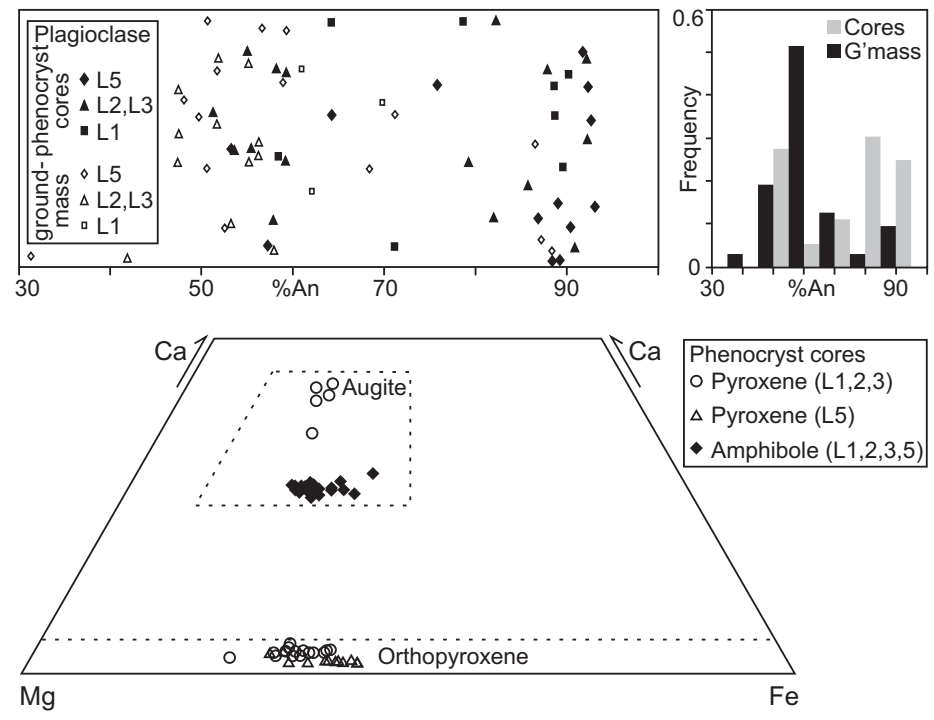

FIG. 5. Top: plagioclase compositions, distinguishing phenocryst core and groundmass analyses. On the left, the scatter on the y-axis is random. The same data are shown on a histogram to the right, showing the bimodality of phenocryst core compositions. Bottom: pyroxene and hornblende compositions for phenocryst cores. Except for subtle differences in the L5 orthopyroxenes, analyses for all samples cover the same compositional fields. Pyroxene subdivisions are shown as dashed outlines. 
in L5 extend into the compositional field of L1-L3. The augite phenocrysts of L2 stand out clearly in figure 5; groundmass augite in L1 covers the same compositional field.

\subsection{Hornblende compositions}

Hornblende commonly occurs as clots with plagioclase in the Huequi lavas, and in some samples is present as megacrysts, either with plagioclase or as isolated grains, of up to $2 \mathrm{~cm}$ in length (Fig. 4). The hornblendes contain small amounts of $\mathrm{Na}$ and $\mathrm{Ti}$, placing them between tschermakitic and pargasitic compositions (Deer et al., 1992). In thin section, hornblende in the andesites has a deep orange-brown colour, and is euhedral with a fine-grained black aggregate rim, containing plagioclase, orthopyroxene and magnetite, of variable thickness. This feature, typical of oxy-hornblende (Deer et al., 1992), results from a dehydroxylation-oxidation reaction during consolidation of the lava. Hornblende in the basaltic andesite has a slightly paler, greener colour. Compositionally, it is not clearly distinguishable from that in the andesites (Fig. 5). In this rock the aggregate jacket is more thickly developed, but the crystal form remains euhedral. Hornblende is not present as a groundmass phase in any samples.

Using the empirical thermobarometric formulations of Ridolfi et al. (2010), amphibole phenocryst core compositions within the Huequi lavas have been used to estimate pressure, temperature, oxygen fugacity and melt water content at the time of amphibole crystallisation (Fig. 6). These results show that hornblende in the L5 andesite, where it is a frequent phase, were sourced from a mid crustal reservoir (960-1003 ${ }^{\circ} \mathrm{C}$; $400-570 \mathrm{MPa}$, implying depths of $15-22 \mathrm{~km}$ ). The hornblende in a coarse-grained clot within the L1 basaltic andesite gives values within the same range, but free phenocrysts, in contrast, give a range extending to much lower values $\left(908-976^{\circ} \mathrm{C}\right.$; 234-483 MPa, implying depths as shallow as $9 \mathrm{~km}$ ). The limited analyses from L2, another andesite, indicate depths shallower than L5 (12-16 km). Hence, amphibole compositions suggest distinct batches of magmas, in spite of shared characteristics, between different eruptions at Huequi. The water contents of the melts are high, ranging from $6.0-7.9 \mathrm{wt} \%$, the highest values corresponding with the deepest samples, those in L5 and the coarse clot in L1.

\section{Geochemistry}

Major and trace element compositions of several Huequi samples have been measured by XRF spectrometry (Table 3), using samples trimmed of weathered material, and powdered in an agate disc mill. Additional trace element measurements were made by solution ICP-MS (Table 3). For this, solutions of $100 \mathrm{mg}$ powdered samples were produced in a multi-stage method, involving initial hot, low-pressure digestion in $\mathrm{HF}$ and $\mathrm{HNO}_{3}$, followed by multiple drying and dissolution steps using $\mathrm{HNO}_{3}$ and $\mathrm{HCl}$, before final dilution in $\mathrm{HNO}_{3}$. For elements analysed by both methods, results compared well $(<10 \%$ deviation from XRF values). XRF standard analyses were within $2 \%$ of reference values; those for ICP-MS were within $5 \%$ ( $15 \%$ for $\mathrm{Gd}, \mathrm{Ta}, \mathrm{U})$.

The Huequi rocks appear to form a coherent suite in terms of both major and trace element compositions and, in agreement with petrological observations, the data suggest a close relationship between samples in terms of magmatic source and history. This relationship is seen in figure 7 , where
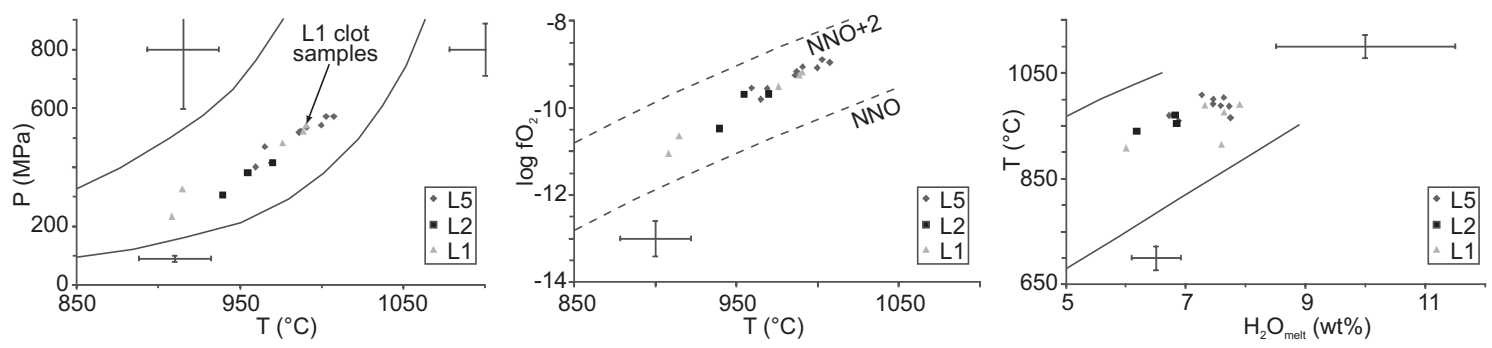

FIG. 6. Thermobarometric relationships for Huequi amphibole compositions, calculated using the method of Ridolfi et al. (2010). Black lines show stability limits of typical calc-alkaline compositions (cf. Ridolfi et al., 2010). Error bars show expected $\mathrm{T}_{\text {and }} \mathrm{fO}_{2}$ errors, and representative uncertainties for changing values of $\mathrm{P}$ and $\mathrm{H}_{2} \mathrm{O}_{\text {melt }}$ (cf. Ridolfi et al., 2010). 
TABLE 3. MAJOR AND TRACE ELEMENT COMPOSITIONS OF HUEQUI ROCK SAMPLES.

\begin{tabular}{|c|c|c|c|c|c|c|c|c|c|}
\hline Unit & L1 & L2 & L3 & L5 & L5 & L5 & T1 & T2(S) & T2(P) \\
\hline Sample & $822-6 B$ & $822-3 A$ & $822-4 E$ & $822-4 B$ & $822-4 C$ & 822-4D & $822-1 \mathrm{~A}$ & $822-6 C$ & $822-6 D$ \\
\hline $\mathrm{SiO}_{2}$ & 54.9 & 58.9 & 59.6 & 58.8 & 59.0 & 59.1 & 62.2 & 53.1 & 53.9 \\
\hline $\mathrm{TiO}_{2}$ & 0.7 & 0.6 & 0.6 & 0.6 & 0.6 & 0.6 & 0.5 & 0.8 & 0.7 \\
\hline $\mathrm{Al}_{2} \mathrm{O}_{3}$ & 19.2 & 18.4 & 18.3 & 18.6 & 18.6 & 18.4 & 17.6 & 19.5 & 18.9 \\
\hline $\mathrm{Fe}_{2} \mathrm{O}_{3}$ & 8.3 & 7.3 & 7.1 & 7.3 & 7.1 & 7.1 & 5.7 & 8.7 & 8.2 \\
\hline $\mathrm{MnO}$ & 0.2 & 0.1 & 0.2 & 0.1 & 0.1 & 0.1 & 0.1 & 0.2 & 0.2 \\
\hline $\mathrm{MgO}$ & 4.2 & 3.0 & 2.6 & 3.2 & 3.1 & 3.1 & 2.1 & 4.6 & 4.4 \\
\hline $\mathrm{CaO}$ & 8.4 & 6.9 & 6.5 & 7.0 & 6.9 & 6.9 & 5.6 & 8.8 & 8.1 \\
\hline $\mathrm{Na}_{2} \mathrm{O}$ & 3.4 & 3.8 & 4.1 & 3.8 & 3.8 & 3.7 & 4.3 & 3.3 & 3.5 \\
\hline $\mathrm{K}_{2} \mathrm{O}$ & 0.5 & 0.8 & 0.8 & 0.8 & 0.8 & 0.8 & 1.0 & 0.5 & 0.5 \\
\hline $\mathrm{P}_{2} \mathrm{O}_{5}$ & 0.2 & 0.2 & 0.2 & 0.2 & 0.2 & 0.2 & 0.2 & 0.2 & 0.2 \\
\hline 1.o.i. & 0.1 & 0.3 & 0.5 & 0.2 & 0.0 & 0.1 & 0.8 & 0.5 & 1.1 \\
\hline Total & 100.1 & 100.3 & 100.4 & 100.5 & 100.2 & 100.1 & 100.1 & 99.9 & 99.5 \\
\hline $\mathrm{Mg} \#$ & 50.6 & 45.3 & 42.8 & 46.6 & 46.4 & 46.4 & 42.9 & 51.4 & 51.60 \\
\hline $\mathrm{Rb}$ & 11 & 20 & 19 & 20 & 19 & 19 & 26 & 10 & 15 \\
\hline $\mathrm{Sr}$ & 394 & 370 & 382 & 421 & 421 & 412 & 391 & 390 & 381 \\
\hline $\mathrm{Y}$ & 19 & 18 & 20 & 18 & 18 & 19 & 18 & 20 & 17 \\
\hline $\mathrm{Zr}$ & 92 & 118 & 125 & 113 & 112 & 115 & 137 & 85 & 90 \\
\hline $\mathrm{Nb}$ & 4 & 5 & 5 & 5 & 5 & 6 & 6 & 5 & 5 \\
\hline $\mathrm{Ba}$ & 171 & 272 & 246 & 293 & 301 & 278 & 429 & 178 & 258 \\
\hline $\mathrm{Sc}$ & 19 & 14 & 12 & 13 & 11 & 13 & 8 & 22 & 16 \\
\hline $\mathrm{V}$ & 153 & 103 & 78 & 83 & 90 & 87 & 37 & 172 & 122 \\
\hline $\mathrm{Cr}$ & 33 & 10 & 19 & 12 & 7 & 8 & 5 & 13 & 18 \\
\hline $\mathrm{Co}$ & 15 & 7 & 7 & 9 & 10 & 11 & 8 & 15 & 12 \\
\hline $\mathrm{Ni}$ & 10 & 5 & 4 & 6 & 4 & 6 & 2 & 8 & 6 \\
\hline $\mathrm{Cu}$ & 19 & 12 & 19 & 17 & 14 & 14 & 8 & 30 & 50 \\
\hline $\mathrm{Zn}$ & 78 & 67 & 77 & 56 & 52 & 57 & 51 & 80 & 68 \\
\hline $\mathrm{Ga}$ & 21 & 20 & 20 & 19 & 19 & 19 & 18 & 20 & 19 \\
\hline $\mathrm{Pb}$ & 5 & 6 & 7 & 7 & 5 & 6 & 10 & - & - \\
\hline As & 8 & 9 & - & 6 & - & 7 & 9 & 7 & - \\
\hline Mo & - & 1.0 & 1.0 & - & - & 1.1 & 1.3 & 0.8 & - \\
\hline $\mathrm{Sn}$ & - & - & 2.0 & - & - & 1.5 & 0.8 & 0.5 & - \\
\hline $\mathrm{La}$ & - & 10.8 & 11.1 & - & - & 12.2 & 14.0 & 7.4 & - \\
\hline $\mathrm{Ce}$ & - & 24.5 & 26.1 & - & - & 27.9 & 31.4 & 18.1 & - \\
\hline $\operatorname{Pr}$ & - & 3.3 & 3.6 & - & - & 3.7 & 4.0 & 2.6 & - \\
\hline $\mathrm{Nd}$ & - & 13.9 & 15.0 & - & - & 15.5 & 16.2 & 12.1 & - \\
\hline $\mathrm{Sm}$ & - & 3.2 & 3.4 & - & - & 3.4 & 3.3 & 3.1 & - \\
\hline $\mathrm{Gd}$ & - & 3.2 & 3.4 & - & - & 3.4 & 3.3 & 3.3 & - \\
\hline $\mathrm{Tb}$ & - & 0.5 & 0.5 & - & - & 0.5 & 0.5 & 0.5 & - \\
\hline Dy & - & 3.1 & 3.1 & - & - & 3.0 & 2.8 & 3.2 & - \\
\hline Ho & - & 0.6 & 0.6 & - & - & 0.6 & 0.6 & 0.6 & - \\
\hline $\mathrm{Er}$ & - & 1.9 & 1.9 & - & - & 1.8 & 1.6 & 1.9 & - \\
\hline $\mathrm{Tm}$ & - & 0.3 & 0.3 & - & - & 0.3 & 0.2 & 0.3 & - \\
\hline $\mathrm{Yb}$ & - & 1.9 & 2.0 & - & - & 1.7 & 1.7 & 1.9 & - \\
\hline $\mathrm{Lu}$ & - & 0.3 & 0.3 & - & - & 0.3 & 0.3 & 0.3 & - \\
\hline $\mathrm{Ta}$ & - & 0.3 & 0.3 & - & - & 0.4 & 0.5 & 0.3 & - \\
\hline $\mathrm{U}$ & - & 0.6 & 0.5 & - & - & 0.5 & 0.7 & 0.3 & - \\
\hline
\end{tabular}

$\mathrm{SiO}_{2}$ to $\mathrm{P}_{2} \mathrm{O}_{5}$ and 1.o.i. (loss on ignition) given in $\mathrm{wt} \%$. Mg\# calculated as $\%$ atomic $\mathrm{Mg} /(\mathrm{Mg}+\mathrm{Fe})$. Total iron given as $\mathrm{Fe}_{2} \mathrm{O}_{3}$. $\mathrm{Rb}$ to $\mathrm{U}$ given in ppm. Oxides and Rb to As measured by XRF at the Open University, Milton Keynes, U.K. Mo to U measured using solution ICP-MS at Oxford University, U.K. 
incompatible element levels increase with increasing magmatic evolution (from the basaltic andesite $\mathrm{T} 2$ to the dacite T1), as well as in the linear fractionation trends seen on variation diagrams (Fig. 8). The low $\mathrm{Nb}$ and Ta concentrations are typical of calc-alkaline arc rocks, while the Ti content, lowest in the more evolved samples, is likely to also reflect crystal fractionation. The suite of rocks is characterised by relatively high $\mathrm{K}$ and $\mathrm{Al}$ contents, while the incompatible element trend (Fig. 7) is relatively steep, with low concentrations of heavy rare earth elements. These patterns are clearer if Huequi is examined in a regional context, and lava samples are compared to those from nearby SSVZ stratovolcanoes in the following section.

\subsection{Regional comparison}

Clear along-arc variations within a range of isotopic and elemental ratios, reflecting changes in crustal thickness, melting and assimilation processes, exist further north in the Andean southern volcanic zone (e.g., Hildreth and Moorbath, 1988). Such patterns are less clear in the region between Calbuco and Hudson, where crustal thickness is relatively constant (Stern, 2004). The main variable here is the age of the subducting slab, which decreases southwards. The exception is Hudson volcano, lying close to the plate triple junction, which forms a clear compositional outlier (cf. Gutiérrez et al., 2005) and is not further discussed here. In spite of large-scale similarities in crustal parameters across the Calbuco-Cay arc segment, clear chemical differences exist between these volcanoes (Figs. 8 and 9). Here, we focus on locations where good data are available (Fig. 1), including volcanoes immediately to the north (Yate and Hornopirén; Watt, 2010) and south (Minchinmávida; López-Escobar et al., 1993) of Huequi, as well as Calbuco to the north (López-Escobar et al., 1993, 1995b) and Mentolat, Maca and Cay to the south (López-Escobar et al., 1993; D’Orazio et al., 2003; Gutiérrez et al., 2005).

On an AFM plot (Irvine and Baragar, 1971) the Huequi rocks fall within the field of other regional volcanics, defining calc-alkaline compositions just below the tholeiitic transition (Fig. 8). However, major element variation plots for alkali elements and alumina clearly distinguish Huequi from neighbouring volcanoes: in its low-K and high-Al character it is similar only to Calbuco and Mentolat within the SSVZ (Fig. 8). The trend in Na-content shows subtle distinctions between most of the region's volcanoes. The petrological characteristic that relates Huequi with Calbuco and Mentolat is the presence of hornblende as a phenocryst phase (López-Escobar et al., 1993, 1995b), and this can be related to the above major element trends. Amphibole has also been documented in dacites at Cay (Stern et al., 1976), but is not widespread there, and in general Cay does not show the shared geochemical characteristics observed between Calbuco, Mentolat and Huequi. However, as shown below, magma genesis and evolution at these amphibolephyric centres is not necessarily closely similar. Petrologically, Huequi is distinctive in containing amphibole as a near ubiquitous (although in some cases uncommon) phase, and across a broad range of silica contents. Furthermore, the amphiboles within Huequi lavas appear close to equilibrium with their host rock, being in all cases euhedral, in contrast with the rarer crystals, rounded and heavily rimmed, at Calbuco or Mentolat.

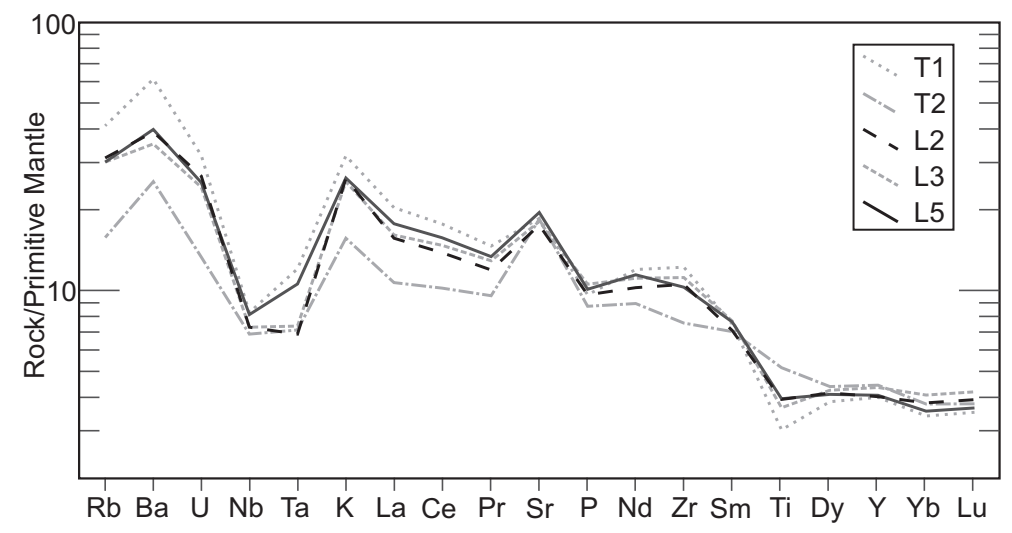

FIG. 7. Incompatible element plot for Huequi lava and tephra samples (Table 3), normalized to primitive mantle compositions (Sun and McDonough, 1979). The plotted data span basaltic-andesitic to dacitic bulk compositions. 

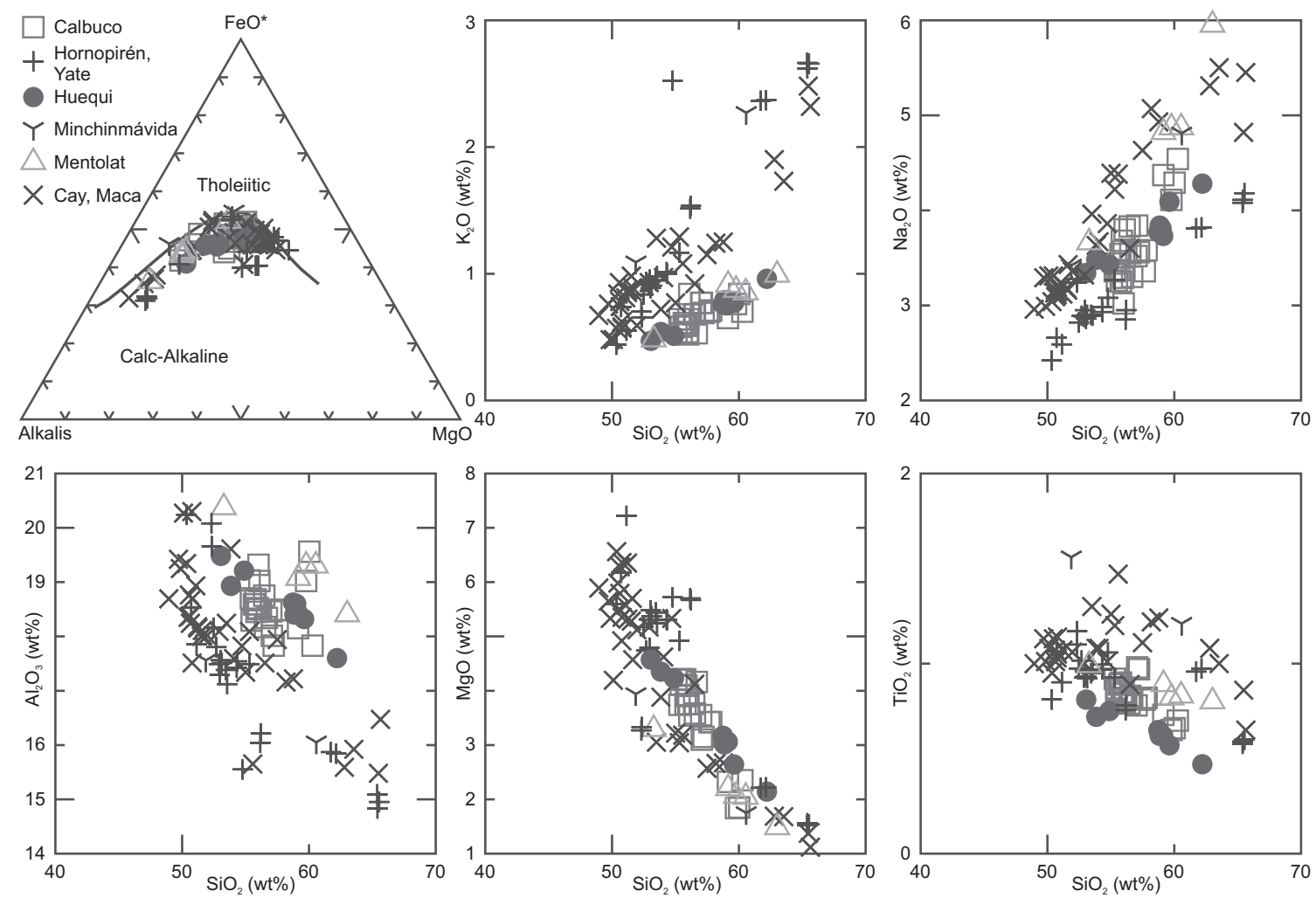

FIG. 8. Total alkali-MgO-FeO* plot (rock classification following Irvine and Baragar, 1971) and variation diagrams showing chemical data from Huequi and selected regional volcanoes (Fig. 1) (López-Escobar et al., 1993, 1995b; D’Orazio et al., 2003; Gutiérrez et al., 2005; Watt, 2010).

\subsection{Implications of distinctive regional charac- teristics}

Amphibole stability in basaltic andesite compositions requires parental liquids to be high in both $\mathrm{H}_{2} \mathrm{O}$ and $\mathrm{Na}_{2} \mathrm{O}$ (Sisson and Grove, 1993). Thus, variation in magma source compositions along this arc segment may broadly explain the presence of amphibole at Huequi, and its absence elsewhere. For example, at Yate and Hornopirén, highly anorthitic plagioclase indicates water-rich magmas, in common with Huequi, but the Na-content of these magmas is notably low (Fig. 8), and unusual in a regional context. The ultimate cause of such variability along this arc segment remains obscure.

Several chemical patterns at Huequi point to high levels of amphibole fractionation, which make the volcano distinct both from the amphibole-absent centres (e.g., Yate, Minchinmávida) and the centres where rare, unstable amphibole is observed in in- termediate lavas (Mentolat, Calbuco). The low-K, high-Al character of Huequi, shared with Calbuco and Mentolat, may, as argued by López-Escobar et al. (1995b), arise through amphibole fractionation, producing relatively elevated silica contents for a given extent of crystallisation. High levels of fractionation may also account for the notably low Ti content at Huequi (e.g., Davidson et al., 2007). Trace element patterns, however, suggest further complexities (Fig. 9). In common with Calbuco and Mentolat, relatively low abundances of highly incompatible elements (e.g., Ba, La) occur at Huequi. While depletion in middle and heavy rare-earth elements, as well as Y, would be expected from amphibole fractionation, there is in fact a pattern of general depletion in incompatible elements for these rocks (Fig. 9). Only levels of Nb are similar to other regional volcanoes. However, a clear difference is seen for $\mathrm{La} / \mathrm{Yb}$ (and similarly $\mathrm{La} / \mathrm{Y}$, not plotted) ratios. The strong linear trend at Huequi is suggestive of 

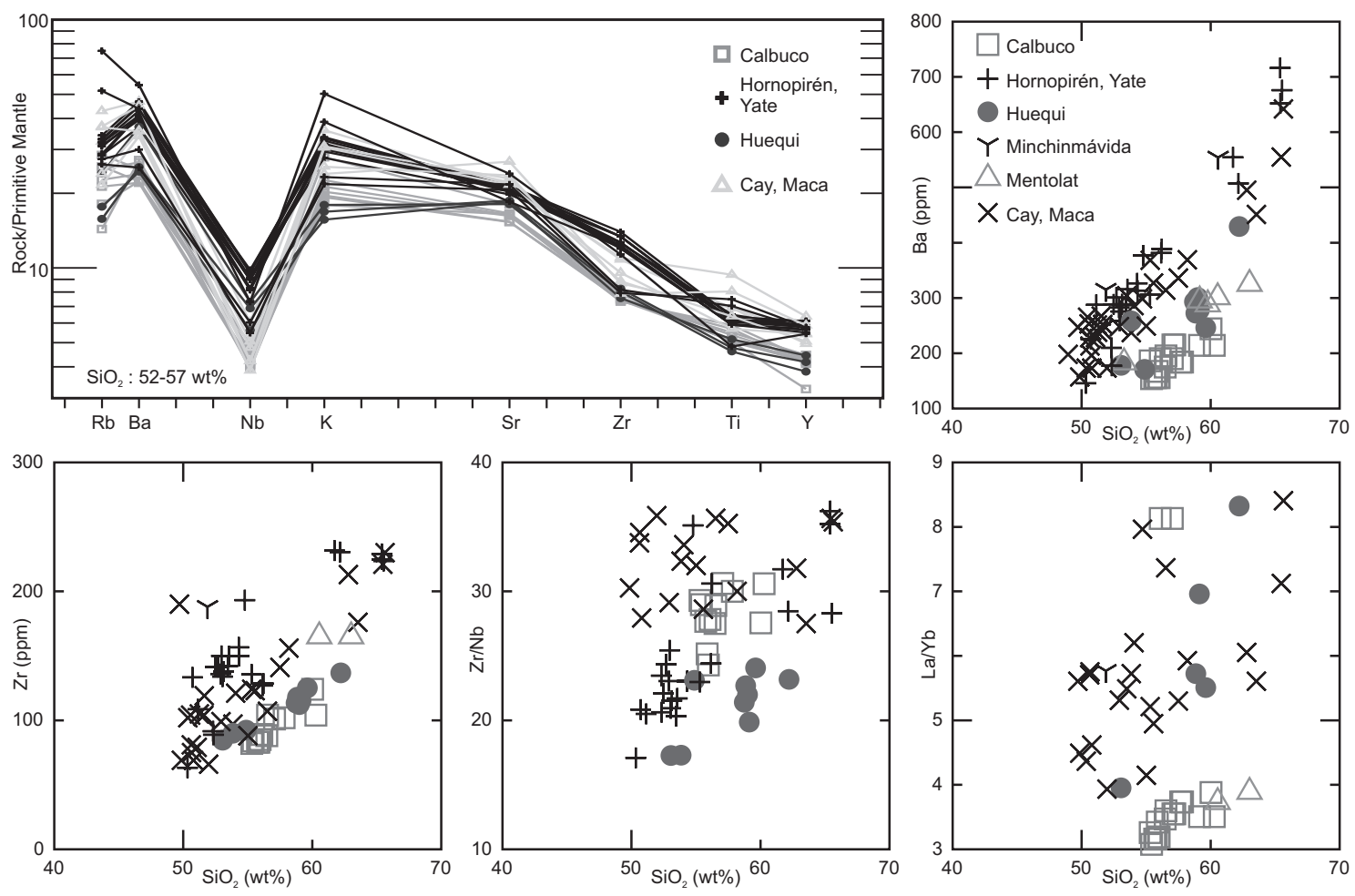

FIG. 9. Incompatible element plot and selected trace element variation and ratio plots for Huequi and selected regional volcanoes (López-Escobar et al., 1993, 1995b; D’Orazio et al., 2003; Gutiérrez et al., 2005; Watt, 2010; Fig. 1). Note difference in key between spider plot and scatter plots. Spider plot is normalised to primitive mantle (Sun and McDonough, 1979) and only includes basaltic andesite $\left(52-57 \mathrm{wt} \% \mathrm{SiO}_{2}\right)$ samples.

significant amphibole fractionation (Davidson et al., 2007), and contrasts with the much more subtle trend at Calbuco and Mentolat. Such trends (as well as a decrease in $\mathrm{Dy} / \mathrm{Yb}$ ) have been used by Davidson et al. (2007) to argue for the widespread importance of cryptic amphibole fractionation in arc magmas, and similar patterns are indeed seen for the SSVZ rocks plotted in figure 9, even though they do not share other characteristic depletions with Huequi, Calbuco and Mentolat. However, the steepness of the $\mathrm{La} / \mathrm{Yb}$ trend at Huequi distinguishes it from all other volcanoes in the region, suggesting notably high levels of fractionation of an amphibole-rich assemblage during magma evolution, a situation consistent with amphibole stability across an unusually wide range of the pressure-temperature-time curve. This concurs with the stability of amphibole across the range of sampled rocks, unique to Huequi in the SSVZ.

The petrological and geochemical characteristics of Huequi are comparable to those found at Nevado de Longaví $\left(36.2^{\circ} \mathrm{S}\right)$, further north in the Andean southern volcanic zone (Sellés et al., 2004). The high values of certain trace element ratios $(\mathrm{La} / \mathrm{Yb}, \mathrm{Sr} / \mathrm{Y})$ at Nevado de Longaví have been termed adakitic by some authors (cf. Zellmer, 2009). These ratios are in fact significantly lower at Huequi than Nevado de Longaví, although Huequi's rocks do still approach the chemical definition of adakitic compositions (Defant and Drummond, 1990). Such compositions have been used to imply magmagenesis involving high heat flux or slab melts (Zellmer, 2009). There is no evidence for any such scenario at Huequi, and we rather suggest that the composition here, as was argued at Nevado de Longaví by Sellés et al. (2004), results from high magmatic water contents. At Nevado de Longaví, this was attributed to a high sub-arc water flux due to fracture-zone subduction. However, there is no evidence for a similar situation within the subduction system beneath Huequi, which appears typical in the context of the arc. Thus, the origin of the water-rich conditions at Huequi, and associated high levels of amphibole stability and 
fractionation, remains unclear and requires further investigation.

\section{Summary and Conclusions}

This first description of the volcanic geology of Huequi shows it to be highly distinctive in the context of the SSVZ, an arc segment for which subduction and crustal parameters are generally uniform. Huequi forms a particularly subdued and eroded edifice, a result of an eruption style restricted to dome-forming eruptions interspersed by explosive activity, giving rise to multiple collapsed domes surrounded by an extensive debris fan.

Petrologically, Huequi's rocks show relatively little variation. The low-K magmas, with hornblende phenocrysts, are unusual regionally. In the few other locations where hornblende occurs as a mineral phase, it is out of equilibrium, in contrast with the euhedral grains at Huequi. In some lavas, hornblende is present as extremely coarse-grained clots, evidence of high levels of amphibole fractionation at depth. Such a conclusion is supported by the geochemistry of the rocks, which suggests a model of an initially waterrich, sodic magma evolving through fractionation, with amphibole stability across a wide compositional range. This wet composition, dominantly producing andesites, is likely to result in high levels of crystallisation upon magma ascent, producing viscous dome porphyries. However, the cause of the unusual magma composition at Huequi, absent elsewhere along this arc-segment, is not readily explained, given a lack of obvious distinction in subduction and crustal parameters between Huequi and other local volcanoes.

\section{Acknowledgements}

S.Watt gratefully acknowledges the field assistance of C. Guzmán, G. Gallardo and M. Gallardo. M. Suárez, Ch. Stern, L. López-Escobar and A. Demant provided reviews and comments that improved the manuscript. We thank D. Sellés for sharing regional petrological data, C. Pyle, L. López-Escobar and A. Demant for Spanish editing, and NERC for funding.

\section{References}

Cembrano, J.; Hervé, F.; Lavenu, A. 1996. The Liquine Ofqui fault zone: a long-lived intra-arc fault system in southern Chile. Tectonophysics 259: 55-66.
Davidson, J.; Turner, S.; Handley, H.; Macpherson, C.; Dosseto, A. 2007. Amphibole 'sponge' in arc crust? Geology 35: 787-790.

Deer, W.A.; Howie, R.A.; Zussman, J. 1992. An introduction to the rock forming minerals. Longman: $696 \mathrm{p}$. London.

Defant, M.J.; Drummond, M.S. 1990. Derivation of some modern arc magmas by melting of young subducted lithosphere. Nature 347: 662-665.

D’Orazio, M.; Innocenti, F.; Manetti, P.; Tamponi, M.; Tonarini, S.; González-Ferrán, O.; Lahsen, A.; Omarini, R. 2003. The Quaternary calc-alkaline volcanism of the Patagonian Andes close to the Chile triple junction: geochemistry and petrogenesis of volcanic rocks from the Cay and Maca volcanoes $\left(45^{\circ} \mathrm{S}\right.$, Chile). Journal of South American Earth Sciences 16: 219-242.

Fuenzalida Izquierdo, J.L. 1979. Estudio geológico preliminar de península Huequi, X Región. Tesis (Unpublished), Universidad de Chile, Departamento de Geología: 158 p.

González-Ferrán, O. 1995. Volcanes de Chile. Instituto Geográfico Militar: 640 p. Santiago.

Gutiérrez, F.; Gioncada, A.; González-Ferrán, O.; Lahsen, A.; Mazzuoli, R. 2005. The Hudson Volcano and surrounding monogenetic centres (Chilean Patagonia): An example of volcanism associated with ridge-trench collision environment. Journal of Volcanology and Geothermal Research 145: 207-233.

Hildreth, W.; Moorbath, S. 1988. Crustal contributions to arc magmatism in the Andes of Central Chile. Contributions to Mineralogy and Petrology 98: 455-489.

Irvine, T.N.; Baragar, W.R.A. 1971. A guide to the chemical classification of the common volcanic rocks. Canadian Journal of Earth Sciences 8: 523-548.

López-Escobar, L.; Kilian, R.; Kempton, P.D.; Tagiri, M. 1993. Petrography and geochemistry of Quaternary rocks from the Southern Volcanic Zone of the Andes between $41^{\circ} 30^{\prime}$ and $46^{\circ} 00^{\prime} \mathrm{S}$, Chile. Revista Geológica de Chile 20: 33-55.

López-Escobar, L.; Cembrano, J.; Moreno, H. 1995a. Geochemistry and tectonics of the Chilean Southern Andes basaltic Quaternary volcanism $\left(37^{\circ}-46^{\circ} \mathrm{S}\right)$. Revista Geológica de Chile 22: 219-234.

López-Escobar, L.; Parada, M.A.; Hickey-Vargas, R.; Frey, F.A.; Kempton, P.D.; Moreno, H. 1995b. Calbuco Volcano and minor eruptive centres distributed along the Liquiñe-Ofqui Fault Zone, Chile $\left(41^{\circ}-42^{\circ} \mathrm{S}\right)$ : contrasting origin of andesitic and basaltic magma in the Southern Volcanic Zone of the Andes. Contributions to Mineralogy and Petrology 119: 345-361. 
Naranjo, J.A.; Stern, C.R. 2004. Holocene tephrochronology of the southernmost part $\left(42^{\circ} 30^{\prime}-45^{\circ} \mathrm{S}\right)$ of the Andean Southern Volcanic Zone. Revista Geológica de Chile 31 (2): 225-240.

Ridolfi, F.; Renzulli, A.; Puerini, M. 2010. Stability and chemical equilibrium of amphibole in calc-alkaline magmas: an overview, new thermobarometric formulations and application to subduction-related volcanoes. Contributions to Mineralogy and Petrology 160: 45-66.

Sellés, D.; Rodríguez, A.C.; Dungan, M.A.; Naranjo, J.A.; Gardeweg, M. 2004. Geochemistry of Nevado de Longaví Volcano $\left(36.2^{\circ} \mathrm{S}\right)$ : a compositionally atypical arc volcano in the Southern Volcanic Zone of the Andes. Revista Geológica de Chile 31 (2): 293-315.

Siebert, L.; Simkin, T. 2002. Volcanoes of the World: an Illustrated Catalog of Holocene Volcanoes and their Eruptions. Smithsonian Institution, Global Volcanism Program Digital Information Series, GVP-3, (http:// www.volcano.si.edu/world/).

Sisson, T.W.; Grove, T.L. 1993. Experimental investigations of the role of $\mathrm{H}_{2} \mathrm{O}$ in calc-alkaline differentiation and subduction zone magmatism. Contributions to Mineralogy and Petrology 113: 143-166.

Sparks, R.S.J.; Murphy, M.D.; Lejeune, A.M.; Watts, R.B.; Barclay, J.; Young, S.R. 2000. Control on the emplacement of the andesite lava dome of the Soufriere Hills volcano, Montserrat by degassing-induced crystallization. Terra Nova 12: 14-20.

Stern, C.R.; Skewes, M.A.; Durán, M. 1976. Volcanismo Orogénico en Chile Austral. In Congreso Geológico de Chile, No. 1, Actas 2: 195-212. Santiago.

Stern, C.R. 2004. Active Andean volcanism: its geologic and tectonic setting. Revista Geológica de Chile 31 (2): 161-206.

Sun, S.S.; McDonough, W.F. 1989. Chemical and isotopic systematics of oceanic basalts: implications for mantle composition and processes. Geological Society, London, Special Publication 42: 313-345.

Watt, S.F.L. 2010. Records of volcanism and controls on volcanic processes in southern Chile. D.Phil thesis, Department of Earth Sciences, University of Oxford, U.K.: 367 p. (http://ora.ouls.ox.ac.uk/).

Watt, S.F.L.; Pyle, D.M.; Mather, T.A.; Martin, R.S.; Matthews, N.E. 2009. Fallout and distribution of volcanic ash over Argentina following the May 2008 explosive eruption of Chaitén, Chile. Journal of Geophysical Research 114: B04207.

Zellmer, G.F. 2009. Petrogenesis of Sr-rich adakitic rocks at volcanic arcs: insights from global variations of eruptive style with plate convergence rates and surface heat flux. Journal of the Geological Society, London 166: $725-734$. 